\title{
Determinants of the Dividend Policy: An Empirical Study on the Lebanese Listed Banks
}

\author{
Christopher Maladjian $^{1}$ \& Rim El Khoury ${ }^{1}$ \\ ${ }^{1}$ Faculty of Business Administration and Economics, Department of Accounting, Finance \& Economics, Notre \\ Dame University, Lebanon
}

Correspondence: Christopher Maladjian, Faculty of Business Administration and Economics, Department of Accounting, Finance \& Economics, Notre Dame University, Main Campus, Zouk Mosbeh, Lebanon. Tel: 961-374-5651. E-mail: clmaladjian@gmail.com

Received: January 10, 2014

Accepted: January 30, 2014

Online Published: March 25, 2014

doi:10.5539/ijef.v6n4p240

URL: http://dx.doi.org/10.5539/ijef.v6n4p240

\begin{abstract}
This research aims at investigating the factors determining the dividend payout policy in the Lebanese banks listed on the Beirut Stock Exchange. This study considers the impact of seven variables, namely, profitability, liquidity, leverage, firm size, growth, firm risk and previous year's dividend payout on the dividend payout ratios by using an unbalanced panel dataset of listed banks between the years of 2005 and 2011. Two models were tested using the OLS and the dynamic panel regressions. Empirical results show that the dividend payout policies are positively affected by the firm size, risk and previous year's dividends, but are negatively affected by the opportunity growth and profitability. The results obtained might indicate that firms pay dividends with the intention of reducing the agency conflicts. Furthermore, managers take into consideration the stability of dividends while determining the dividend policy. Moreover, the results suggest that the Lebanese listed firms prefer to invest their earnings to grow rather than to pay more dividends.
\end{abstract}

Keywords: dividend policy, dynamic panel, OLS, Lintner's model, Beirut stock exchange

\section{Introduction}

Dividend policy is one of the most controversial issues in modern corporate finance. Black (1976) argues that "the harder we look at the dividend picture, the more it seems like a puzzle, with pieces that just don't fit together". This mystery led to the emergence of a handful of competing theoretical and empirical research to explain why companies pay or do not pay dividends. After two decades of non-stop research, the dividend policy is still listed as one of the top ten crucial unresolved issues in the world of finance in which no consensus has been reached (Brealey \& Myers, 2003).

The examination of the dividend policy in the emerging stock markets has, until recently, been more limited than in the developed markets. This paper aims to determine the dividend payout of Lebanon-an emerging country in the Middle East. More specifically, this paper focuses on the banking sector since it is considered as a backbone of the Lebanese economy, accounting for 35\% of the GDP growth. Given the strength of the Lebanese banking sector, individual investors as well as institutions have been extensively interested in becoming shareholders. Eventually, this expands the need to recognize the driving elements of the dividend payment policy in this sector. Despite the importance of the banking sector in the Lebanese economy, the examination of the dividend policy in the Lebanese listed banks has been limited. Therefore, this study seeks to fill this gap by conducting an empirical analysis on the determinants of the dividend payout of Lebanese banks listed on the Beirut Stock Exchange (BSE). The specific objectives of this paper are (i) to apply previously used dividend models, mainly the Lintner Model, on the Lebanese listed banks and (ii) to ascertain the determinants of the dividend payout ratio in the Lebanese banking industry.

The rest of the paper is organized as follows: section 2 presents previous empirical findings in developed and in emerging countries, while section 3 discusses the data and variables. Section 4 describes the research methodology and tests the underlying assumptions and Section 5 presents and discusses the empirical findings. Finally, section 6 concludes. 


\section{Literature Review}

Although many theories and models have been attempted to examine the determinants of the dividend policy, the roots of the empirical literature has been credited to John Lintner (1956) who conducted his study on American companies in the middle of 1950s. He concluded that the dividend decision is based upon the current profitability and the previous year's dividends. Subsequently, there has been an ongoing debate on the dividend policy resulting in controversial and inconclusive results. Many researchers tested Lintner's model ability to explain the dividend decision process in U.S firms (Darling, 1957; Dhrymes \& Kurz, 1964; Fama \& Babiak, 1968; Baker et al., 1985; Fama \& French, 1997; Shirvani \& Wilbratte, 1997) and in emerging economies (Mookerjee, 1992; Glen et al., 1995; Aivazian et al., 1999). For example, Fama and Babiak (1968) tested the Lintner model on the dividend data of 392 major North American industrial firms and concluded that Lintner's dividend model has succeeded well in explaining the dividend changes of individual firms.

The ground breaking seminal article by Miller \& Modigliani (MM) in 1961 that introduced the dividend irrelevance theory altered the mentality of many researchers regarding the dividend policy. MM argued that in a perfect market condition (Note 1), the dividend decision is irrelevant since it has no impact on the value of the firm or on the shareholders' wealth. However, the presence of market imperfections has provided the basis for the development of various theories which undermined the dividend irrelevance theory. Therefore, since Miller \& Modigliani (1961) introduced the dividend irrelevance hypothesis and Black (1976) addressed the "Dividend Puzzle" in their studies, a number of researchers tried to solve this puzzle to learn the most important determinants of the dividend policy. Many of the studies concluded that dividend payment behavior in emerging countries is significantly different than that of developed markets. Factors such as culture, perceptions, market size, market depth, efficiency, regulations and taxation, make emerging countries a special case.

The review of the empirical studies in this section focuses on those conducted in emerging countries generally and on banks specifically since 1990s and it is presented chronologically.

\subsection{Empirical Findings on Corporate Dividend Decisions in Emerging Countries}

Mookerjee (1992) was the first who used Lintner's model in an emerging country. He investigated the dividend behavior in the Indian market from 1949 to 1981 . He concluded that Lintner's model explained the dividend behaviors in the Indian environment. Furthermore, Indian firms believe that they should pay dividends even if their profit level is low and even if they have to go for external financing (borrowing).

Annuar and Shamsher (1993) investigated the dividends behavior of firms listed on the Kuala Lumpur Stock Exchange (now known as Bursa Malaysia). They found that firms' dividend decisions partially depended on their current profits and past dividends. They also found that firms have long-term target dividends, which is conditioned upon their earnings ability.

Aivazian et al. (2003) examined the dividend policy of a sample of companies from eight emerging markets, and compared them to a sample of 99 US companies. They found that emerging firms displayed dividend behaviors similar to US firms, in the sense that dividends are explained by profitability, debt, and the market-to-book ratio. However, the sensitivity to these variables varies across countries.

Amidu and Abor (2006) conducted a study on the determinants of dividend payout ratios in Ghana during a six-year period. Using an Ordinary Least Squares model, the results showed positive relationships between dividend payout ratios and profitability, cash flow, and tax. The results also showed negative associations between dividend payout and risk, institutional holding, growth and market-to-book value. However, the significant variables in the results were only profitability, cash flow, sales growth and market-to-book value.

Al Yahyaee (2006) examined the dividend policy of Omani firms in the financial and non-financial sectors between 1989 and 2004. The results suggested that profitability, size, and business risk affect the dividend policy of both financial and non-financial firms. However, government ownership, leverage, and age had a strong influence on the dividend policy of non-financial firms with no effect on financial firms. On the other hand, agency costs, tangibility, and growth factors did not appear to have any significant impact on the dividend policy of both financial and non-financial firms.

Al-Malkawi (2007) examined the determinants of corporate dividend policy in Jordan using a firm-level panel data set of all publicly traded firms on the Amman Stock Exchange between 1989 and 2000. Using Tobit specifications, the results suggested that the firm's age, size, and profitability positively and significantly affected its dividend policy, while leverage negatively affected the dividend policy.

Al-Twaijry (2007) conducted a research on the dividend policy of 300 firms listed on the Kuala Lumpur stock exchange. The results showed that there were no significant associations between the dividend payout ratios and 
the past, present or future net earnings. However, there was a significant negative correlation between the company's financial leverage and its dividend policy.

Al Kuwari (2009) used a panel dataset of nonfinancial firms listed on Gulf Co-operation Council (GCC) countries between 1999 and 2003. Using a series of random effect Tobit models, the results suggested that the dividend policy was strongly and directly related to the government ownership, firm size and firm profitability, but negatively to the leverage ratio. He concluded that firms pay dividends with the objective of reducing the agency problem and maintaining firms' reputation.

Parua and Gupta (2009) undertook a research on the determinants and trends of dividends in 607 listed Indian companies from 1993 to 2005 . They found that past, current and expected future profits had significant positive role in determining the dividend payout ratio. Evidence showed that the cash balance and cash flow had significant negative relationship with the dividend rate. Factors like Interest expense, capital expenditure, tax ratio and share price had almost no role on the dividend payment.

Okpara (2010) analyzed the determinants of the dividend Payout policy of firms from Nigerian Securities and Exchange Commission. They found that profitability negatively affected the payout ratio whereas liquidity and previous year's dividend exerted a positive impact on the payout ratio. Therefore, they concluded that these three factors (profit, liquidity and previous year's dividends) were good predictors of the dividend payout policy in Nigeria.

Al Ajmi and Hussain (2011) aimed to study the dividend decisions of a sample of 54 Saudi Arabian listed firms during 1990-2006. They found that Saudi firms had more flexible dividend policies since they were willing to cut or skip dividends when profit declines and pay no dividends when losses were reported. Lagged dividend payments, profitability and cash flows were found to be determinants of dividend payments.

Imran (2011) empirically investigated the factors affecting the dividend payout decisions of Pakistan engineering sector using the data of 36 listed firms during 1996-2008. Using various panel data techniques, he found that the dividend payout was positively affected by last year's dividend, earning per share, profitability, sales growth and the size of the firm, whereas it was negatively affected by the cash flow.

Finally, Sinaei and Habibi (2012) aimed to study the determinants of the dividend payout ratio on firms listed in The Tehran's Stock Exchange (TSE) from 1999 to 2008. The results showed that there was a significant and negative relationship between the dividend payout ratio and market-to-book ratio and capital expenditure. On the other hand, there was a positive relationship with the compensation and debt to equity ratio (financial leverage).

\subsection{Empirical Findings on Bank Dividend Decisions}

Gupta and Walker (1975) were one of the first who provided the banking-related study on dividend policy. They analyzed 980 banking firms from 1965 to 1968 and found a positive relationship between dividends and current profits, the change in profits from the prior year, the sum of profits over time, and the growth in total assets. However, they found a negative relationship between the liquidity and the bank's dividend payout.

Kennedy and Nunnally (1986) studied the dividend payout ratios of 80 large banking firms for 1982-1983 using several regression techniques. The results showed that prior year's dividend payout ratio and the stock's price-earnings (PE) ratio were consistently considered as important determinant variables.

Mercado-Mendez and Willey (1995) examined the agency costs of 104 largest U.S, banking firms during 19851989. The only variable with a significant relationship to the dividend yield was the total assets. They concluded that banks use more dividends to control for agency costs.

Dickens et al. (2002) examined bank dividend policy and its variables in USA using 4,112 firm observations from 1998-2000. The analysis suggested a negative relationship between dividend payments and investment opportunities, signaling, ownership, and risk. However, there was a positive relationship between size and dividend history.

Lee (2009) investigated the determinants of dividend policy in Korean banking industry using a panel data of Korean banks during 1994-2005. The study found a positive relationship between the bank's profitability, bank's size, and the dividend payout. They concluded that because banks were subject to monitoring and surveillance from their regulator on their operations, the dividend policy would be more closely associated with their riskiness.

Kinfe (2011) undertook an empirical study on the determinants of dividend payout of six private banks in Ethiopia during 2006 to 2010. By using Lintner's model, the study concluded that there was a positive relationship between the firm size and the dividend payout ratio, a negative relationship between liquidity and 
the dividend payout. However, there was no relationship between payout ratio and profitability, growth and leverage. He concluded that banks in Ethiopia considered agency conflicts, previous year's dividend and liquidity when making decisions to pay dividends.

Marfo-Yiadom and Agyei (2011) carried out the same study on sixteen banks in Ghana covering a five year period (1999-2003). The results showed that profitability, leverage, changes in dividends and collateral capacity had a positive significant impact on the dividend policies of banks in Ghana. On the other hand, they found that growth and firm maturity had a negative significant influence on the dividend payout. However, the cash flow had a negative, but insignificant relationship with the dividend policy.

\section{Data and Variables}

\subsection{Source of Data}

The study is based on unbalanced panel of Lebanese commercial banks listed on Beirut Stock Exchange (BSE). The variables examined in this study consist of secondary yearly data collected mainly from Bilan Banques and Bankscope database that contains the financial statements of Lebanese banks. Since the latest period of available data on Bankscope is 2005, the time frame of the research will be limited to the period from 2005-2011. In this study, a purposive sampling technique is employed in selecting banks. To be included in the analysis, the bank must meet three criteria, which are (i) having regular annual report and account for the study period; (ii) showing positive earnings throughout the period of the study; (iii) paying continuous dividend payout throughout the period of the study. After the above filtering, only four listed banks will be included in this study, which are BLOM bank, Audi bank, Byblos bank, and Bank of Beirut.

\subsection{Variables Definition}

\subsubsection{Dependent Variable}

In line with previous studies that examined the main determinants of dividend payment, the dependent variable used in this study is the dividend payout ratio (DPR), defined as the dividend paid divided by net income (Rozeff, 1982; Lloyd, 1985; Amidu \& Abor, 2006). This variable measures the percentage of the company's earning distributed to shareholders.

\subsubsection{Independent Variables}

Although there are plenty of potential determinants for the dividend decisions, the explanatory variables that are included in this study are only internal variables which consist of profitability, size, liquidity, leverage, risk, growth and previous year's dividend.

\section{a. Profitability (PROF)}

Profitability, in this study, is measured as Return on Equity or Net income divided by Total equity (Freeman et al., 1982). It has been found as one of the most essential determinants of dividend payout policy (Lintner, 1956; Pruitt \& Gitman, 1991; Deangelo et al., 2004; Amidu \& Abor, 2006). According to the signaling theory of dividend policy, profitable firms are willing to pay higher amounts of dividends to convey their good financial performance (Bhattacharya, 1979; Chang \& Rhee, 1990; Ho, 2003; Aivazian et al., 2003). Therefore, a positive relationship is expected between firm's profitability and its dividend payments.

\section{b. Firm Size (SZ)}

The size of the bank is measured by the natural logarithm of total assets as used by Gill et al. (2009) and is included to account for size variability. Large companies tend to be more competitive, with access to capital, better credit rating, and more customers, which will enhance their profitability and increase their ability to pay higher dividends (Dickens et al., 2002). Supporting this logic, Lloyd et al. (1985), Jensen et al. (1992), Redding (1997), Holder et al. (1998), Fama and French (2001), Aivazian et al. (2003) and Sawicki (2005) found a positive relationship between dividend payout policy and firm size.

\section{c. Liquidity (LIQ)}

Measured by the current ratio, which is equal to current assets divided by current liabilities (Kania \& Bacon, 2005; Kanwal \& Kapoor, 2008; Ahmed \& Javid, 2009), liquidity is an essential factor that affects the dividend policy. According to the signaling theory, firms with higher cash accessibility are able to pay higher dividends than firms with insufficient cash (Ho, 2003). Furthermore, according to the agency theory of cash flow, Jensen (1986) argued that firms with high cash flows pay higher dividends in order to diminish the agency conflict between their managers and shareholders. Otherwise, managers may pursue their own personal agenda and maximize their personal wealth instead of maximizing the wealth of its shareholders. 


\section{d. Growth opportunities (GRO)}

The change in revenues (interest and non-interest revenues) is used as a proxy for growth opportunities. If a firm is growing rapidly, the more is the need for funds to finance the expansion, and the more likely the firm is to retain earning rather than to pay them as dividends (Chang \& Rhee, 1990). Consequently, firms with higher growth opportunities are likely to retain a greater portion of their earning, resulting in lower dividend payout ratio ( Higgins, 1972; Rozeff, 1982; Jensen et al., 1992; Alli et al., 1993; Mohammed et al., 2006).

\section{e. Financial leverage (LEV)}

To analyze the extent to which debt can affect dividend payouts, the ratio of deposits (both short-term and long term deposits) to total assets is used as a proxy for leverage. The empirical evidence regarding the effect of leverage on dividend payout is mixed. Some studies found that firms with high debt ratios are willing to pay fewer dividends (Jensen et al., 1992; Agrawal \& Jayaraman, 1994; Faccio et al., 2001; Gugler \& Yurtoglu, 2003; Al-Malkawi, 2005) since they are committed to fixed payments to service their debt, which restrict the distribution of dividends. Furthermore, banks with higher leverage ratio are under regulatory pressure which puts a restriction on paying high dividends (Dickens et al., 2002). However, Kania and Bacon (2005) have found a significant positive relationship, concluding that firms might use debt funds to pay dividends.

\section{f. Firm Risk (PE)}

Although risk can be measured in different ways, it will be proxied by the $\mathrm{P} / \mathrm{E}$ ratio defined as the market price per share divided by Earning per share since it implicitly incorporates the perceived risk of a given company's future earnings (Fama \& French 1998; Friend \& Puckett, 1964). Although Mollah et al. (2002) found that firms listed on the Dhaka Stock Exchange paid a large dividend even though they are considered risky, majority of researchers have demonstrated a strong negative relationship between the level of riskiness and dividend payout ratio (Rozeff, 1982; Al-Kuwari, 2009; Al-Shubiri, 2011). Since high PEs may be linked with low risk, it might lead to higher payout ratios.

\section{g. Previous year's dividends (PYD)}

In the real world, it is often believed that companies pay a steady stream of dividends because investors perceive firms with stable dividends as stronger and more valuable. Lintner (1956) showed that historical dividends are essential in determining current dividends. The model was tested and reaffirmed by Fama \& Babiak (1968), Ahmed \& Javid (2009) and Mollah (2009) who concluded that the previous year's dividends positively affect the current dividend payout ratio of a company. In this study, the last year's dividends payout is used as a proxy variable for historical dividends.

All variables used in this study are defined in Table 1 along with the expected sign.

Table 1. Variables with their symbols and expectations

\begin{tabular}{lllc}
\hline Variables & Symbol & \multicolumn{1}{c}{ Description } & Expectation \\
\hline Dividend Payout & DPR & Cash Dividend/ Net profit & + \\
Profitability & PROF & ROE = Net Profit less Preference Dividends/ Shareholder's equity & + \\
Firm Size & SZ & Natural Logarithm of Total Assets & + \\
Liquidity & LIQ & Current Assets/ Current Liability & - \\
Growth Opportunity & GRO & (Current Revenue - previous Revenue)/previous sales & $-/+$ \\
Financial Leverage & LEV & Debt/ Total assets & $-/+$ \\
Firm Risk & PE & Market Price Per share/Earning per share & + \\
Previous Year's Dividends & PYD & Previous Year's Dividend Payout & \\
\hline
\end{tabular}

Computed by authors.

\section{Methodology}

\subsection{Model Specification}

Although the data consists of both cross sectional and time series information, it does not contain equal information of all banks in the sample for the entire period. Therefore, unbalanced panel estimation techniques are used in this study. Panel techniques take into account the heterogeneity present among individual banks, and allow the study of the impact of all factors with less collinearity among variables, more degree of freedom and greater efficiency. 
Similarly to previous studies, a linear regression is used to capture the effect of various factors on banks' dividend payout ratio, as follows:

$$
y=\alpha+\beta_{i t} x+e_{i t}
$$

Where: $y$ represents the dependent variable, which is the firm's dividend payout ratio;

$X$ contains the set of explanatory variables in the model mentioned above, which are PROF, LIQ, GRO, SZ, LEV, $\mathrm{PE}$, and PYD;

$e_{i, t}$ is the disturbance term;

$\alpha$ is taken to be constant over time $t$ and specific to the individual cross-sectional unit I;

$i$ and $t$ denote the cross-sectional and time-series dimension respectively;

All tests necessary for the empirical study are performed using STATA.

\subsection{CLRM Assumptions}

To maintain the data validity and robustness of the regressed result of the research, the basic classical linear regression model (CRLM) assumptions must be tested for identifying any misspecification and correcting them so as to augment the research quality. There are seven CLRM assumptions that need to be satisfied and that are tested in this study, which are: errors equal zero mean test, stationarity, normality, homoscedasticity, autocorrelation, multicollinearity and linearity tests.

\subsubsection{Assumption 1: The Errors Have Zero Mean (E (e) =0)}

According to Brooks (2008), if a constant term is included in the regression equation, this assumption will never be violated. Thus, the regression model used in this study will include a constant term, even if not significant.

\subsubsection{Assumption 2: Unit-Root Test (Stationary Test)}

Stationarity implies that the mean, variance, and autocorrelation of a variable do not change over time. The absence of stationarity-Nonstationarity- can strongly influence the behavior and properties of the series, so that the tests about the regression parameters cannot be validated (Sarbapriya, 2012). In this study, stationarity of the data is tested using Fisher test-a unit root test for unbalanced panels as suggested by Maddala and Wu (1999), where a $\mathrm{p}$-value greater than $5 \%$ indicates that the data has a unit root test and is non-stationary. The Fisher test can be calculated in two methods: taking into consideration the augmented Dickey-Fuller (ADF) test or taking into consideration the Philips Perron test (PP). According to Sarbapriya (2012), the PP test provides better results than ADF test and it attempts to satisfy the stationarity conditions for all the variables. Therefore, PP test is used to check the stationarity of this study, although both methods gave similar results.

Results reported in Table 2 indicate that all the variables are stationary, except the SZ variable, which is stationary only at lag 1 . Since including SZ variable as one lag in the regression will make us lose some observations, we will run two models: (1) One including the lag of "SZ" variable, and (2) one excluding the lag of "SZ" variable. The impact of "SZ" variable is assessed by the improvement in the overall explanatory power of the equation. If the firm size is a significant variable, the one lag value of this variable will be included in the regression.

Table 2. Fisher-type unit-root test based on Phillips-Perron tests

\begin{tabular}{cccc}
\hline Variables & Lags & chi-squared & p-value \\
\hline Dividend Payout & 0 & 73.5005 & 0.0000 \\
PROF & 0 & 145.4379 & 0.0000 \\
LEV & 0 & 36.6703 & 0.0000 \\
PE & 0 & 19.5565 & 0.0122 \\
LIQ & 0 & 26.4366 & 0.0009 \\
SZ & 1 & 20.3498 & 0.0091 \\
GRO & 0 & 84.4458 & 0.0000 \\
PYD & 0 & 75.8825 & 0.0000 \\
\hline
\end{tabular}

Computed by authors using STATA. Ho: All panels contain unit roots, Number of panels = 4; Ha: At least one panel is stationary, Number of periods $=7$. 


\subsubsection{Assumption 3: The Normality Test}

The normality assumption assumes that the errors of prediction are normally distributed. The Skewness-Kurtosis, ShapiroWilk, Shapiro- Francia tests, in addition to QQ plot of residuals and Bera- Jarcques Statistics might be used to check the null hypothesis that the sample is drawn from a normally distributed population (Park, 2002). Three types of tests will be used to check whether residuals are normal. Specifically, two numerical methods (Jarque Berra test and Shapiro-Wilk test) and one graphical method (Quantile-Quantile Plots (Q-Q Plot)) will be conducted.

First, the Bera-Jarque statistic would not be significant and p-value should be greater than $5 \%$ if the residuals are normally distributed (Brooks, 2008). The results in Table 3 report a P-value of 0.35 , higher than 0.05 , suggesting that normality assumption holds. Second, and since Shapiro-Wilk is more appropriate for small sample sizes (less than 50 samples) (Woolridge, 2002), Table 4 presents the results for this test. Similarly, the reported P-value of 0.36 , which is greater than the significance level of 0.05 , suggests that data are normal.

Table 3. Jarque Berra test

\begin{tabular}{|c|c|c|c|c|c|}
\hline \multicolumn{6}{|c|}{ Skewness/Kurtosis tests for Normality } \\
\hline Variable & Obs & $\operatorname{Pr}($ Skewness $)$ & $\operatorname{Pr}($ Kurtosis $)$ & $\operatorname{adj} \operatorname{chi2(2)}$ & Prob $>$ chi 2 \\
\hline Residuals & 24 & 0.1856 & 0.7232 & 2.07 & 0.3549 \\
\hline
\end{tabular}

Computed by authors using STATA.

Table 4. Shapiro-Wilk test

\begin{tabular}{|c|c|c|c|c|c|}
\hline \multicolumn{6}{|c|}{ Shapiro-Wilk W test for normal data } \\
\hline Variable & Obs & W & $\mathrm{V}$ & $\mathrm{z}$ & Prob $>z$ \\
\hline Residuals & 24 & 0.95592 & 1.189 & 0.353 & 0.3619 \\
\hline
\end{tabular}

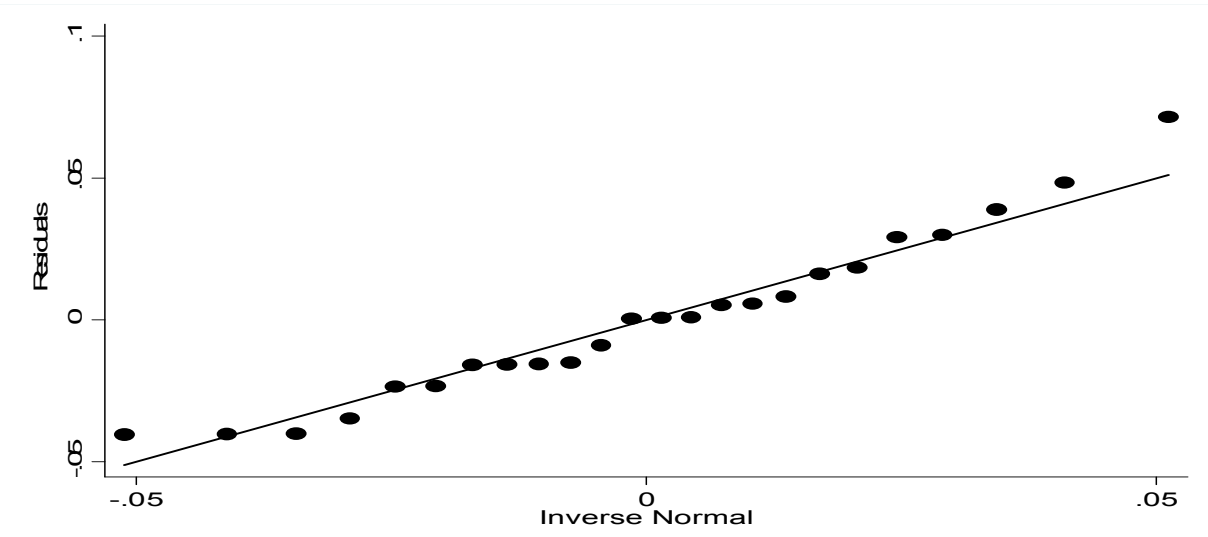

Figure 1. Normal Q-Q plot for studentized residuals

Computed by authors using STATA.

Lastly, normality will be tested graphically using the output of a normal Q-Q Plot. Since the data points in Figure 1 are close to the diagonal line, the data is normally distributed.

\subsubsection{Assumption 4: The Homoscedasticity Test}

To test for homoscedasticity, the Breush-Pagan Test and the White test will be used. Results reported in Table 5 indicate that the null hypothesis cannot be rejected since the p-values of both tests are considerably greater than 0.05. The results conclude that there is homoscedasticity so no further corrections for the sample are required. 
Table 5. Breusch Pagan test and White test

\begin{tabular}{|c|c|c|c|}
\hline \multicolumn{2}{|c|}{ Breusch-Pagan Test } & \multicolumn{2}{|c|}{$\begin{array}{l}\text { White's test } \\
\end{array}$} \\
\hline \multicolumn{2}{|c|}{ Ho: Constant variance } & \multicolumn{2}{|c|}{$\begin{array}{c}\text { Ho: homoskedasticity } \\
\text { Ha: unrestricted heteroscedasticity }\end{array}$} \\
\hline chi2 & 0.72 & chi2 & 24.00 \\
\hline$P$-value & 0.3966 & $P$-value & 0.4038 \\
\hline
\end{tabular}

Computed by authors using STATA.

\subsubsection{Assumption 5: The Autocorrelation Test}

In the presence of residuals autocorrelation, statistical inferences can be misleading. Since the Durbin Watson test is only applicable to test autocorrelation in time series, this study uses Wooldridge (2002) test appropriate in panel-data models where a significant test statistic indicates the presence of serial correlation. The P-value of the test is greater than 5\% as shown in Table 6, suggesting the presence of no autocorrelation of errors. Drukker (2003) provided simulation results showing that the test has good size and power properties in reasonably sized samples.

Table 6. Wooldridge test

Computed by authors using STATA.

\begin{tabular}{cc}
\hline Wooldridge test for autocorrelation in panel data \\
\hline H0: no first order autocorrelation \\
$F(1,3)$ & 1.878 \\
$P r o b>F$ & 0.2641 \\
\hline
\end{tabular}

\subsubsection{Assumption 6: The Multicollinearity Test}

Multicollinearity refers to the situation in which independent variables are highly correlated; resulting in a paradoxical effect, whereby the regression model fits the data well, but none of the independent variables has a significant impact in predicting the dependent variable (Gujarati, 2004). Among several ways of multicollinearity tests, Pearson coefficient of correlation between variables and Variance Inflation Factor (VIF) are used detect any problem.

Table 7 reports the Pearson correlation of the variables used in the regressions. As observed from the table, multicollinearity is not a serious problem since majority of correlation coefficients are below 0.75 (Malhotra, 2004).

Table 7. Pearson correlation test of explanatory variables

\begin{tabular}{cccccccc}
\hline & PROF & LEV & LIQ & GRO & PE & PYD & lagSZ \\
\hline PROF & 1.0000 & & & & & & \\
LEV & 0.0288 & 1.0000 & & & & & \\
LIQ & 0.3502 & -0.1165 & 1.0000 & & & & \\
GRO & -0.1401 & 0.0006 & 0.1343 & 1.0000 & & & \\
PE & -0.4658 & 0.1873 & -0.0252 & 0.2773 & 1.0000 & & \\
PYD & 0.4099 & 0.1668 & 0.0002 & 0.2242 & 0.2709 & 1.0000 & 1.0000 \\
Lag SZ & 0.6361 & 0.1511 & 0.0625 & -0.0355 & -0.6102 & 0.1545 & \\
\hline
\end{tabular}

Computed by authors using STATA.

Furthermore, the existence of multicollinearity is tested by calculating the Variance Inflation Factor (VIF) where a VIF coefficient greater than 10 indicates the presence of multicollienarity (Chatterjee \& Price, 1977). The results in Table 8 report a mean VIF of 2.16, which is much lower than the limit of 10. The VIFs for individual variables was also very low, supporting the previous conclusion that the explanatory variables included in the model are not substantially correlated with each other. 
Table 8. Variance Inflation Factor (VIF) of the explanatory variables

\begin{tabular}{lll}
\cline { 2 - 3 } Variable & VIF & Tolerance \\
\cline { 2 - 4 } PROF & 3.52 & 0.284332 \\
PE & 2.88 & 0.346729 \\
lagSZ & 2.59 & 0.386163 \\
PYD & 2.19 & 0.457387 \\
LIQ & 1.47 & 0.681787 \\
GRO & 1.29 & 0.773213 \\
LEV & 1.21 & 0.825747 \\
Mean VIF & 2.16 & \\
\hline
\end{tabular}

Computed by authors using STATA.

\subsubsection{Assumption 7: Linearity Test}

Finally, linearity is usually most evident in a plot of the observed versus predicted values or a plot of residuals versus predicted values. A preferable method of detection is the examination of residual plots. Since the points are symmetrically distributed around a diagonal line in the P-P plot in Figure 2, linearity is not a problem in our data.

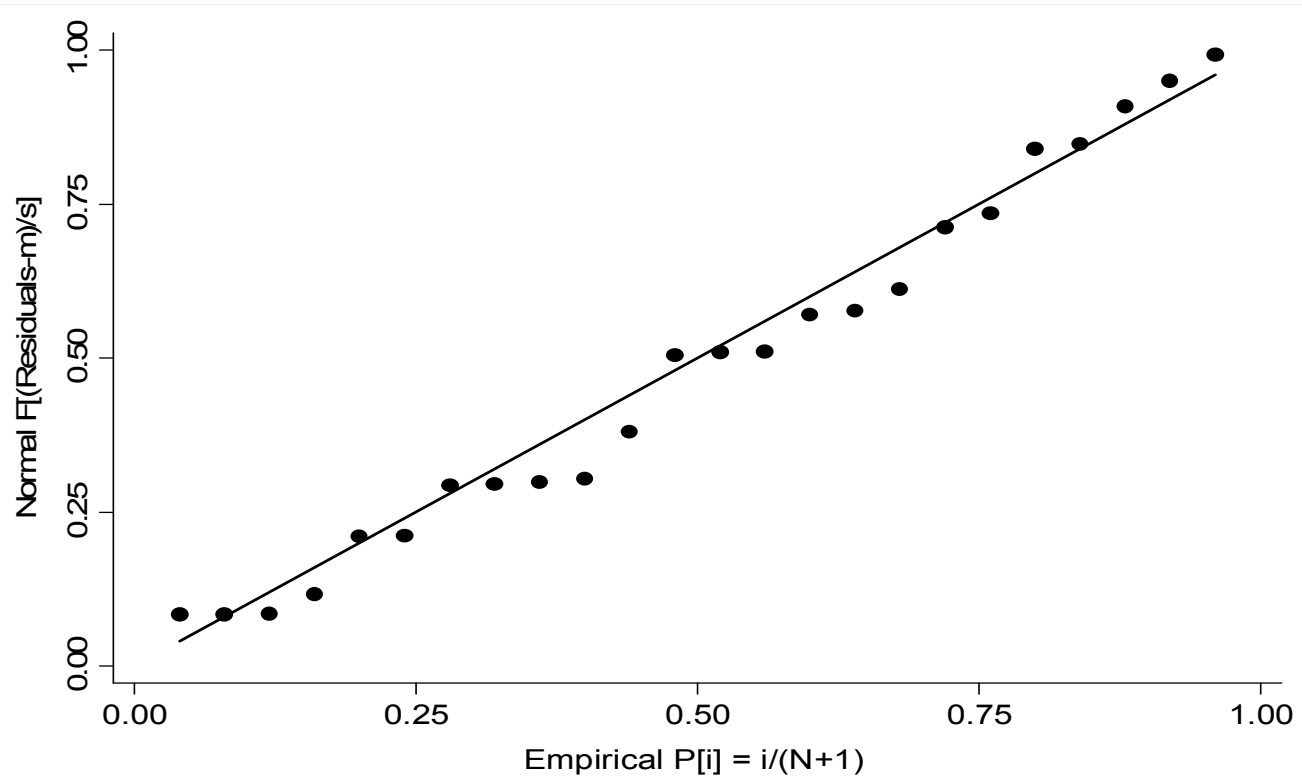

Figure 2. Normal PP plot of regression standardized residual

Computed by authors using STATA.

\subsection{Choice of Regression}

The results so far indicate that all CRLM assumptions are not violated, so the ordinary least square regression can be safely applied.

However, since this study uses a panel data, there are two types of panel estimator approaches that can be employed, namely: fixed effects models (FEM) and random effects models (REM) (Brooks, 2008). To examine whether individual effects are fixed or random, a Hausman specification test (Baltagi, 2005) was conducted providing evidence in favor of the REM model as presented in Table 9 (p-value for both tests are $28 \%$ and $56 \%$ respectively). This result supports Baltagi's (2005) recommendation that the random effects (RE) method is an efficient estimator for the unbalanced panel models (Baltagi, 2005). 
Table 9. Hausman test of cases I and II

\begin{tabular}{cc}
\hline \multicolumn{3}{c}{ Hausman Test } \\
\hline Case I: Using lag $S Z$ & Case II: without $S Z$ \\
$\operatorname{chi} 2(7)=8.60$ & $\operatorname{chi} 2(6)=4.84$ \\
Prob $>$ chi2 $=0.2823$ & Prob $>$ chi $2=0.5640$ \\
\hline
\end{tabular}

Computed by authors using STATA.

Afterwards, to choose between the random effect and the pooled OLS, the Lagrange multiplier test (LM). The null hypothesis in the LM test is that variance across entities is zero. The result reported in Table 10 shows a p-value greater than $10 \%$, so that we fail to reject the null hypothesis and conclude that the random effect in both cases is not the appropriate method. Therefore, we can run a simple OLS regression

Table 10. Lagrangian multiplier test for random effects

\begin{tabular}{cc}
\hline \multicolumn{2}{c}{ Lagrangian multiplier test for random effects } \\
\cline { 2 - 3 } Case I: Using lag $S Z$ & Case II: Without $S Z$ \\
Prob $=1.0000$ & Prob $=1.0000$ \\
\hline
\end{tabular}

Computed by authors using STATA.

\subsection{Dynamic Panel Data}

Since bank's dividend payout ratio may exhibit a certain degree of persistence over time, the lagged dividend payout is included in the independent variables. The magnitude and the significance of this variable might suggest the presence of a dynamic nature of the model. Therefore, Arellano-Bond (1991) panel data test will be run where the declared endogenous variable occurs as an explanatory variable in a delayed form.

\section{Empirical Results and Discussion}

\subsection{Descriptive Statistics}

Table 11 provides a summary of the descriptive statistics of all variables for the four listed Lebanese banks for a period of seven years from year 2005-2011 with a total of 28 observations. The table reports the mean, standard deviation, number of observations, minimum and maximum of all variables to give an overall description of data used and to serve as data screening tool to spot unreasonable figure.

Table 11. Descriptive statistics

\begin{tabular}{llllll}
\cline { 2 - 6 } Variable & Obs & Mean & Std. Dev. & Min & Max \\
\cline { 2 - 6 } Div payout & 28 & .3151712 & .069769 & .1864021 & .4207732 \\
PROF & 28 & .1256013 & .025594 & .0931866 & .1748346 \\
LEV & 28 & 9.845365 & 2.572428 & .0124135 & 14.93614 \\
SZ & 28 & 16.75062 & .5527737 & 15.6882 & 17.58414 \\
LIQ & 28 & .4180964 & .117309 & .2426 & .7369 \\
GRO & 28 & .2385063 & .1748022 & .0271954 & .6795626 \\
PE & 26 & 9.765716 & 4.238197 & 3.631264 & 18.07265 \\
PYD & 28 & .3218438 & .0676328 & .1864021 & .4207732 \\
\hline
\end{tabular}

Computed by authors using STATA.

According to the table, most variables comprise 28 observations except the PE ratio. This is due to missing reported figure from Bankscope. Variables with any missing values will be dropped, leading to 26 observations, which will be used in the regression. Variables of leverage and price-earning ratio present larger standard deviation as compared with other variables. The means of the dividend payout ratio and the previous year dividend payout ratio are similar, being 31.5 and 32 percent, respectively.

\subsection{Regression Results}

After testing all CLRM assumptions, four econometric specifications were used to find the determinants of 
dividend policy in Lebanese banks. First, Lintner's model will be replicated using the data obtained from the Lebanese listed banks (Model 1). Then, Models 2 and 3 extend Lintner Model by including additional explanatory variables. While one lag of size variable is included in Model 2, it is excluded in Model 3. All these models are based on OLS regression. Finally, Model 4 reports the regression results using a Dynamic Panel Model.

\subsubsection{Lintner's Dividend Model}

To replicate Lintner's model in the Lebanese listed banks, the only variables included are the earning per share and its lagged dividend payments, with dividends used as a dependent variable.

Table 12. OLS Regression- Lintner's model

\begin{tabular}{llc}
\cline { 2 - 3 } & \multicolumn{3}{c}{ OLS Regression- Model 1 } \\
\cline { 2 - 3 } EPS & .0695796 & P-value \\
LDP & .8681437 & 0.257 \\
Number of obs $=28$ & $0.000^{* * *}$ \\
Adj R-squared $=0.9684$ & \\
$\mathrm{~F}=644.49$ & \\
*** indicates significant at 1\% significance level. Computed by authors using STATA.
\end{tabular}

The results in Table 12 show that the coefficient of lagged dividend payments is positive and statistically significant, consistent with previous studies in emerging markets (Ahmed \& Javid, 2009; Al-Ajmi \& Hussain, 2011). However, the coefficient of EPS, although positive, is statistically insignificant. These findings are consistent with those reported by Aivazian et al. (2003) who found that firms in some emerging capital markets do not follow a stable dividend policy. The result clearly indicates the importance of lagged dividends on current year's dividend decisions. The adjusted $\mathrm{R}^{2}$ value reveals that the existing model explains 96.8 percent of the dividend payout pattern of the Lebanese listed banks.

\subsubsection{Determinants of the Dividend Payout Ratio}

Models 2 and 3 try to investigate the determinants of dividend payouts by including several additional variables. The pooled OLS regression was used as an extension of Lintner's model to examine whether PROF, LIQ, LEV, SZ, GRO, PE and PYD are significant determinants of the dividend payments. Model 2 reports the results including one lag of the size variable, while Model 3 presents the results excluding the size variable.

The results in Table 13 reveal that Model 2 is more efficient in estimating the regression results, with a higher regression fit of 73.89 percent, higher $F$ value of 10.30, and with a larger number of significant explanatory variables than Model 3. The results suggest that adding the control variable (lag SZ) improves the explanatory power of the regression. Because Model 2 is better, the discussion of the regression results will be based the model which includes the lag SZ.

Table 13. Determinants of dividend payout OLS and arellano bond regression

\begin{tabular}{lllllll}
\hline & \multicolumn{2}{c}{ Model 2: Using lag SZ } & \multicolumn{2}{c}{ Model 3: without SZ } & \multicolumn{2}{c}{ Model 4: Arellano Bond Model } \\
Coef. & $\mathbf{P}>|\mathbf{t}|$ & Coef. & \multicolumn{1}{c}{$\begin{array}{c}\text { P }>|\mathbf{t}| \\
\mathbf{P}>|\mathbf{t}|\end{array}$} \\
\hline PROF & -1.570964 & $0.009^{* *}$ & -.5689751 & 0.369 & -1.410305 & 0.085 \\
LEV & .0212759 & 0.630 & .0733147 & 0.245 & .0288521 & 0.519 \\
LIQ & .063731 & 0.391 & .0144196 & 0.887 & .0738701 & 0.378 \\
GRO & -.1062898 & $0.049^{*}$ & -.1126452 & 0.109 & -.1239107 & $0.036^{*}$ \\
PE & .0017633 & 0.555 & -.0013341 & 0.700 & .0125416 & $0.019^{*}$ \\
PYD & .8887931 & $0.000^{* *}$ & .8347557 & $0.001^{* *}$ & - & - \\
LagSZ & .0879873 & $0.001^{* *}$ & - & - & .1254849 & $0.017^{*}$ \\
Number of obs F $=$ & 24 & & 26 & & 20 & - \\
Adj R-squared $=$ & 10.30 & & 4.17 & & 48.75 & \\
Chi2 $=$ & 0.7389 & & 0.4320 & & & \\
\hline
\end{tabular}

$*, * *$ indicates significant at $5 \%$ and $1 \%$ significance level respectively. Computed by authors using STATA. 


\subsubsection{Profitability}

Although the sign of the coefficient was not as expected, the coefficient of the profitability is negative and statistically significant at a one percent level as reported in Table 13. Supporting this logic, Okpara (2010) concluded that when firms experience surplus earnings, they allocate most of them into retention for the plugging back and growth of the firm. Furthermore, Ferris, et al. (2003) found that firms in the United Kingdom pay dividends while they had negative earnings. However; the findings are contradicted by Pruitt and Gitman (1991), Baker and Powell (2000), Aivizian et al (2003) and Amidu and Abor (2006). The reconciliation between the two results may rest on the difference between the samples used.

\subsubsection{Firm Size}

Firm size is a statistically significant determinant of the dividend policy consistent with the findings of Redding (1997) and Fama and French (2001) that the probability of paying dividends increases with firm size. Larger firms pay higher cash dividends for several reasons. First, large firms face high agency costs as a result of ownership dispersion (Rozeff, 1992). Second, as a result of the weak control in monitoring the management in large firms, a large dividend payout increases the need for external financing, which in turn leads to the increased monitoring of these firms by the creditors. Third, large firms have easier access to capital markets, and they are able to raise funds with lower issuance costs for external financing (Lloyd et al., 1985; Fama \& French, 2002). Consequently, large firms are better able to distribute higher dividends to shareholders than small firms.

\subsubsection{Liquidity}

Liquidity displays a positive expected sign, but the coefficient is insignificant. Although Jensen et al. (1992), Rozeff (1982) and Easterbrook (1984) argued that companies with high liquidity have to pay higher dividends in order to reduce the agency conflict between managers and shareholders, the results in Table 13 suggests that liquidity is not one of the determinants of dividend payments in Lebanese banks.

\subsubsection{Growth}

As expected, Table 13 shows that the relationship between growth and dividend payout policies is negative and significant at five percent significance level with a p-value of 0.049 . Therefore, growing banks require more funds in order to finance their growth and therefore would typically retain greater proportion of their earnings by paying low dividends, supporting the agency theory and the life-cycle theory.

This means that Lebanese listed banks with high growth opportunities tend to pay fewer dividends, a view supported by Higgins (1972), who noticed that dividend payout ratio is negatively related to a firm's need for funds to finance growth opportunity.

\subsubsection{Financial Leverage}

Against all odds, financial leverage has a positive relationship with the dividend policy, suggesting that banks might use debt to distribute dividends (Dhillon, 1986; Chang \& Rhee, 1990). Despite its positive sign, the financial leverage is insignificant, suggesting that this variable is not an essential factor in influencing dividend payments in Lebanese banks.

\subsubsection{Firm Risk}

As expected, the result shows a positive relationship between PE and dividend payout ratios. Risky firms (Low PE) with high volatility in their cash flows have more difficulty in planning for future investments which will increase their need for external financing, resulting in a lower dividend payout ratio. According to the pecking order theory and because external financing is more expensive, companies choose to decrease their dividend payouts in order to avoid the expensive external financing (Rozeff, 1982; Al-Kuwari, 2009; Al-Shubiri, 2011).

Despite its positive coefficient, the variable is not significant, so it is not an essential factor in influencing dividend payments in Lebanese banks.

\subsubsection{Previous Year's Dividend Payments}

Previous year's dividends were also found to be statistically determinant variable of the dividend payout ratio in the Lebanese listed banks. The results show that the coefficient of previous year's dividend payments is positive, similar to numerous studies on emerging markets such as Al-Ajmi and Hussain (2011) and Ahmed and Javid (2009).

The magnitude and significance of the coefficient on the previous year's dividends might suggest a dynamic nature of the model. Results using the dynamic panel data model are reported in Model 4. In general, the results are similar to Model 2, with the exception of PE which becomes significant. Thus, according to the model, the 
firm risk is an essential factor in influencing the dividend payments of the Lebanese listed banks.

\section{Summary and Concluding Remarks}

The main purpose of the study was to examine the relationship between the dividend payout ratio and certain bank selected factors. Both OLS and dynamic panel model regression were run on a sample of four Lebanese listed banks on Beirut Stock Exchange between 2005 and 2011. The bank selected factors included in the study were firm profitability, size, liquidity, leverage, risk, growth, and previous year dividends.

When applying Lintner's model (1956) on our sample, only the lagged dividends is statistically significant which clearly indicate the importance of lagged dividends on the current year's dividend decisions.

While testing the impact of the seven explanatory variables factors on the dividend payout ratio, we concluded that only five can explain the dividend policy. The firm size is positive and significant, supporting the idea that larger firms have easier access to fund and are able to distribute dividends to shareholders better than smaller firms. The results also suggest that large banks choose to pay more dividends to diminish agency conflicts and maintain bank's reputation. The negative and significant relationship between profitability and dividend policy gave us two diverse interpretations. The first one is explained by the current situation in Lebanon. The political instability of the country obliges banks to use the surplus earnings to allocate most of them into retention for the plugging back for harsh economical periods. The other explanation is that the surplus earnings of the firm are being allocated mostly to the growth opportunities of the company so that the banks can open new branches in different regions and countries where they found projects with positive NPV. Since both the growth opportunity and the profitability are negatively significant on the dividends, we can assume that they are inter-related. Furthermore, the previous year's dividend payout was the most essential variable that affected dividend payout ratio of the banks, which means that last year's dividends affect today's dividend policy. Finally, the last variable is the firm risk, whose significance depends on the model used. The significance of this variable could be due to the fact that banks that enter into high risk ventures are able to attract premium interest that boosts their returns.

Two variables appeared to be statistically insignificant: the financial leverage, and the liquidity. This suggests that these variables do not have a direct influence on the dividend payments. In other words, Lebanese listed banks take into account the firm size, last year's dividends, profitability, and growth and to a less extent the risk, more than the leverage and liquidity, when they are making decisions to pay dividends.

The empirical study suffers from many limitations. The first limitation is the small sample size with a short time frame. Second, although we have cross sectional time series data, some of the financial data collected were missing resulting in an unbalanced data. Third, only seven bank selected factors were included in the research. It is possible that other factors might have a greater impact on the dividend payout ratio than the ones included in the research. For example, the inclusion of additional variables such as the firm maturity, insider ownership, capital structure and institutional ownership of the firm could be examined. Furthermore, the application of macroeconomic variables is another potential extension of the present research.

Understanding the determinants of dividend policy has significant implication on investors and portfolio analysts. Investors who want to select the dividend paying firms might have to look into the five mentioned factors before selecting the bank. Furthermore, the board of directors of the Lebanese listed banks should give consideration to profitability, growth, previous years' dividends, firm size and risk when they set the dividend policy as they are found to be the most significant variables that affect the dividend policy of listed banks. This will help them to make an efficient, effective, and reasonable dividend payout decision which in the long run will help them to achieve their objective of maximizing profit and satisfying employees and shareholders' needs.

\section{References}

Agrawal, A., \& Jayaraman, N. (1994). The dividend policies of all equity firms: A direct test of free cash flow theory. Managerial Decision Economics, 15, 139-148. http://dx.doi.org/10.1002/mde.4090150206

Ahmed, H., \& Javid, A. (2009). Dynamics and determinants of dividend policy in Pakistan: Evidence from Karachi stock exchange non-financial listed firms. International Research Journal of Finance and Economics, 29, 110-125.

Aivazian, V., Booth, L., \& Cleary, S. (1999). Signaling, dividends and financial structure: Implications from cross country comparisons. Rotman School of Management, Finance.

Aivazian, V., Booth, L., \& Cleary, S. (2003). Do emerging market firms follow different dividend policies from US firms? Journal of Financial Research, 26(3), 371-387. http://dx.doi.org/10.1111/1475-6803.00064

Al-Ajmi, J., \& Hussain, H. (2011). Corporate dividends decisions: Evidence from Saudi Arabia. The Journal of 
Risk Finance, 12(1), 41-56. http://dx.doi.org/10.1108/15265941111100067

Al-Kuwari, D. (2009). Determinants of the dividend policy in emerging stock exchanges: The case of GCC countries. Global Economy \& Finance Journal, 2(2), 38-63.

Alli, K. L., Khan, A. Q., \& Ramirez, G. G. (1993). Determinants of corporate dividend policy: A factorial analysis. The Financial Review, 28(4), 523-547. http://dx.doi.org/10.1111/j.1540-6288.1993.tb01361.x

Al-Malkawi, H. N. (2005). Dividend policy of publicly quoted companies in emerging markets: The case of Jordan. (Unpublished doctoral dissertation). School of Economics and Finance, University of Western Sydney, Sydney.

Al-Malkawi, H. N. (2007). Determinants of corporate dividend policy in Jordan: An application of the Tobit model. Journal of Economic and Administrative Sciences, 23(2), 44-70. http://dx.doi.org/10.1108/10264116200700007

Al-Shubiri, F. (2011). Determinants of changes dividend behavior policy: Evidence from the Amman stock exchange. Far East Journal of Psychology and Business, 4(2), 1-15.

Al-Twaijry, A. (2007). Dividend policy and payout ratio: Evidence from the Kuala Lumpur stock exchange. The Journal of Risk Finance, 8(4), 349-363. http://dx.doi.org/10.1108/15265940710777306

Al-Yahyaee, K. (2006). Capital structure and dividend policy in a personal tax free environment: The case of Oman. (Unpublished PhD Dissertation). University of New South Wales, Australia.

Amidu, M., \& Abor, J. (2006). Determinants of dividend payout ratios in Ghana. The Journal of Risk Finance, 7(2), 136-145. http://dx.doi.org/10.1108/15265940610648580

Annuar, M. N., \& Shamsher, M. (1993). The dividend and earnings behavior of firms on the Kuala Lumpur stock exchange pertanika. Journal of Social Sciences and Humanities, 10, 73-84.

Arellano, M., \& Bond, S. (1991). Some tests of specification for panel data: Monte Carlo evidence and an application to employment equations. Review of Economic Studies, 58, 277-297. http://dx.doi.org/10.2307/2297968

Baker, H. K., Farrelly, G. E., \& Edleman, R. B. (1985). A survey of management views on dividend policy. Financial Management, 14(3), 1007-1034. http://dx.doi.org/10.2307/3665062

Baker, H. K., \& Powell, G. (2000). Determinants of corporate dividend policy: A survey of NYSE firms. Finance Practice and Education, 10(1), 29-40.

Baltagi, B. H. (2005). Econometric analysis of panel data econometric analysis of panel data (3rd ed.). Wiley.

Bhattacharya, S. (1979). Imperfect information, dividend policy, and "The Bird in the Hand" Fallacy. The Bell Journal of Economics, 10(1), 259-270. http://dx.doi.org/10.2307/3003330

Bilan, B. (n.d.). Bank data financial services. Lebanon.

Black, F. (1976). The dividend puzzle. Journal of Portfolio Management, 2, 5-8. http://dx.doi.org/10.3905/jpm.1976.408558

Brealey, R. A., \& Myers, S. C. (2003). Principles of corporate finance (7th ed.). New York: McGraw Hill.

Brooks, C. (2008). Introductory econometrics for finance (2nd ed.). New York: Cambridge University Press. http://dx.doi.org/10.1017/CBO9780511841644

Chang, R. P., \& Rhee, S. G. (1990). The impact of personal taxes on corporate dividend policy and capital structure decisions. Financial Management Association, 19(2), 21-31. http://dx.doi.org/10.2307/3665631

Chatterjee, S., \& Price, B. (1977). Regression analysis by example. New York: Wiley.

Darling, P. G. (1957). The influence of expectations and liquidity on dividend policy. Journal of Political Economy, 65(3), 209-224. http://dx.doi.org/10.1086/257920

DeAngelo, H., DeAngelo, L., \& Skinner, D. (2004). Are dividends disappearing? Dividend concentration and the consolidation of earnings. Journal of Financial Economics, 72, 425-456. http://dx.doi.org/10.1016/S0304-405X(03)00186-7

Dhrymes, P. J., \& Kurz, M. (1964). On the dividend policies of electric utilities. The Review of Economic and Statistics, 46(1), 76-81. http://dx.doi.org/10.2307/1924078

Dhillon, U. P. (1986). Corporate ownership, dividend policy, and capital structure under asymmetric information. 
(Ph.D. Thesis) Louisiana State University and Agricultural \& Mechanical College.

Dickens, R. N., Casey, M., \& Newman, J. (2002). Bank dividend policy: Explanatory factors. Journal of Business and Economics, 41, 3-12.

Drukker, D. (2003). Testing for serial correlation in Linear Panel-Data models. The Stata Journal, 3(2), $168-177$.

D’Souza, J. (1999). Agency cost, market risk, investment opportunities and dividend policy an international perspective. Managerial Finance, 25(6), 35-43. http://dx.doi.org/10.1108/03074359910765993

Easterbrook, F. H. (1984). Two agency-cost explanations on dividends. American Economic Review, 74, 650659.

Faccio, M., Lang, L., \& Young, L. (2001). Dividends and expropriation. American Economic Review, 91, 54-78. http://dx.doi.org/10.1257/aer.91.1.54.

Fama, E., \& Babiak, H. (1968). Dividend policy of individual firms: An empirical analysis. Journal of the American Statistical Association, 63, 1132-1161. http://dx.doi.org/10.1080/01621459.1968.10480917

Fama, E., \& French, K. (1997). Industry costs of equity. Journal of Financial Economics, 43, $153-193$. http://dx.doi.org/10.1016/S0304-405X(96)00896-3

Fama, E., \& French, K. (1998). Value versus Growth: The international evidence. Journal of Finance, 53, 19751999. http://dx.doi.org/10.1111/0022-1082.00080

Fama, E., \& French, K. (2001). Disappearing dividends: Changing firm characteristics or lower propensity to pay. Journal of Financial Economics, 60, 3-43. http://dx.doi.org/10.1016/S0304-405X(01)00038-1

Fama, E., \& French, K. (2002). Testing tradeoff and pecking order predictions about dividends and debt. Review of Financial Studies, 15, 1-33. http://dx.doi.org/10.1093/rfs/15.1.1

Ferris, S., Jagannathan, M., \& Pritchard, A. (2003). Too busy to mind the business? Monitoring by directors with multiple board appointments. Journal of Finance, 58, 1087-1111. http://dx.doi.org/10.1111/1540-6261.00559

Freeman, R. N., Ohlson, J. A., \& Penman, S. H. (1982). Book rate-of-return and prediction of earnings changes: An empirical investigation. Journal of Accounting Research, 20(2), 639-653. http://dx.doi.org/10.2307/2490890

Friend, I., \& Puckett, M. (1964). Dividends and stock prices. The American Economic Review, 5(54), 656-682.

Gill, A., Biger, N., Pai, C., \& Bhutani, S. (2009). The determinants of capital structure in the service industry: evidence from United States. Open Bus Journal, 2, $48-53$. http://dx.doi.org/10.2174/1874915100902010048

Glen, J., Karmokolias, Y., Miller, R., \& Shah, S. (1995). Dividend policy and behavior in emerging markets. IFC Discussion Paper No.26.

Gugler, K., \& Yurtoglu, B. (2003). Corporate governance and dividend pay-out policy in Germany. European Economic Review, 47, 731-758. http://dx.doi.org/10.2139/ssrn.275917

Gujarati, N. (2004). Basic econometrics. Singapore: McGraw-Hill.

Gupta, M. C., \& Walker, D. A. (1975). Dividend disbursal practices in commercial banking. Journal of Financial and Quantitative Analysis, 10(3), 515-529. http://dx.doi.org/10.2307/2330494

Higgins, R. C. (1972). The corporate dividend-saving decision. Journal of Financial and Quantitative Analysis, 7(2), 1527-1541. http://dx.doi.org/10.2307/2329932

Ho, H. (2003). Dividend policies in Australia and Japan. International Advances in Economic Research, 9(2), 91-100. http://dx.doi.org/10.1007/BF02295710

Holder, M. E., Langrehr, F. W., \& Hexter, J. L. (1998). Dividend policy determinants: An investigation of the influences of stakeholder theory. Financial Management, 27(3), 73-82. http://dx.doi.org/10.2307/3666276

Imran, K. (2011). Determinants of dividend payout policy: A case of Pakistan engineering sector. The Romanian Economic Journal, 41, 47-59.

Jensen, G., Solberg, D., \& Zorn, T. (1992). Simultaneous determination of insider ownership, debt, and dividend policies. Journal of Financial and Quantitative Analysis, 27, 247-263. http://dx.doi.org/10.2307/2331370

Jensen, M. C. (1986). Agency costs of free cash flow, corporate-finance, and takeovers. American Economic 
Review, 76(2), 323-329. http://dx.doi.org/10.2139/ssrn.99580

Kania, S. L., \& Bacon, F. W. (2005). What factors motivate the corporate dividend decision? American Society of Business and Behavioral Sciences E-Journal, 1(1), 95-107.

Kanwal, A., \& Kapoor, S. (2008). Determinants of dividend payout ratios: a study of Indian information technology sector. International Research Journal of Finance and Economics, 15, 63-71.

Kennedy, W. F., \& Nunnally, B. H. Jr. (1986). An empirical examination of large bank dividend payout ratios, 1982-1983. Financial Review, 21(3), 48. http://dx.doi.org/10.1111/j.1540-6288.1986.tb00712.x

Kinfe, T. (2011). Determinants of dividend payout: An empirical study on banking industry in Ethiopia 20062010. (Unpublished Master Thesis). Addis Ababa University.

Lee, S. W. (2009). Determinants of dividend policy in Korean banking industry. Banks and Bank Systems, 4, 6771.

Lintner, J. (1956). Distribution of incomes of corporations among dividends, retained earnings, and taxes. American Economic Review, 46(2), 97-113.

Lloyd, W. P., Jahera, S. J., \& Page, D. E. (1985). Agency cost and dividend payout ratios. Quarterly Journal of Business and Economics, 24(3), 19-29. http://dx.doi.org/10.1111/j.1540-6288.1985.tb00256.x

Maddala, G. S., \& Wu, S. (1999). Cross-country growth regressions: Problems of heterogeneity, stability and interpretation. Applied Economics, 32, 635-642. http://dx.doi.org/10.1080/000368400322534

Malhotra, N. K. (2004). Marketing research: An applied orientation (4th ed.). Upper Saddle: Prentice-Hall.

Marfo-Yiadom, E., \& Agyei, S. A. (2011). Determinants of dividend policy of banks in Ghana. International Research Journal of Finance and Economics, 61, 99-108.

Mercado-Mendez, J., \& Willey, T. (1995). Agency costs in the banking industry: An examination of ownership behavior, leverage, and dividend policies. Journal of Economics and Finance, 19(3), 105-117. http://dx.doi.org/10.1007/BF02920617

Miller, M. H., \& Modigliani, F. (1961). Dividend policy, growth, and the valuation of shares. Journal of Business, 34, 411-433. http://dx.doi.org/10.1086/294442

Mohammed, E., Oyelere, P., \& Al Jifri, K. (2006). State corporate governance in Oman: Progress has been rapid, sophistication has increased, but there is still room for improvement. Journal of Taxation and Regulation of Financial Institutions, 22, 70-78.

Mollah, S. A. (2009). Testing partial adjustment behavioral models in emerging markets: Evidence from pre and post market reforms in Bangladesh. Global Journal of Business Research, 3(1), 1-14.

Mollah, S., Keasey, K., \& Short, H. (2002). The influence of agency costs on dividend policy in an emerging market: Evidence from the Dhaka stock exchange. Working Paper, Leeds university Business school.

Mookerjee, R. (1992). An empirical investigation of corporate dividend payout behavior in an emerging market. Applied Financial Economics, 2(4), 243-246. http://dx.doi.org/10.1080/758527107

Okpara, G. C. (2010). A diagnosis of the determinant of dividend pay-out policy in Nigeria: A factor analytical approach. American Journal of Scientific Research, 8, 57-67.

Park, H. (2002). Univariate analysis and normality test using SAS, Stata, and SPSS. Working paper, Indiana: University Information Technology Services, Indiana University.

Parua, A., \& Gupta, A. (2009). Dividend history and determinants in selected Indian companies. Australasian Accounting Business and Finance Journal, 3(4), 45-86.

Pruitt, S. W., \& Gitman, L. W. (1991). The interactions between the investment, financing, and dividend decisions of major US firms. Financial Review, 26(33), 409-430. http://dx.doi.org/10.1111/j.1540-6288.1991.tb00388.x

Redding, L. (1997). Firm size and dividend payouts. Journal of Financial Intermediation, 6, 3-38. http://dx.doi.org/10.1006/jfin.1997.0221

Rozeff, M. S. (1982). Growth, beta and agency costs as determinants of dividend payout ratios. Journal of Financial Research, 5(3), 249-259.

Rozeff, M. S. (1992). How companies set their dividend-payout ratios. The Revolution in Corporate Finance, Oxford: Blackwell Publishers. 
Sarbapriya, R, (2012). Empirical testing of international fisher effect in United States and selected Asian economies. AITM, World Science Publisher, 2(1), 187-201.

Sawicki, J. (2005). An investigation into the dividend of firms in East Asia. Working Paper, Nanyang Technological University, Singapore.

Shirvani, H., \& Wilbratte, B. (1997). The relationship between the real exchange rate and the trade balance: An empirical reassessment. International Economic Journal, 11(1), 39-50. http://dx.doi.org/10.1080/10168739700000003

Sinaei, A., \& Habibi, L. (2012). An investigation of factors relevant to payout ratio in listed firms on the Tehran stock exchange. International Journal of Multidisciplinary Management Studies, 2(2), 22-37.

Wooldridge, J. (2002). Econometric analysis of cross section and panel data. Massachusetts London: The MIT Press Cambridge.

\section{Note}

Note 1. The perfect market is where there are no taxes, transaction or flotation cost and no agency costs or contracting cost associated with stock ownership. Markets are complete and frictionless, and all firms are assumed to have the same risk class.

\section{Copyrights}

Copyright for this article is retained by the author(s), with first publication rights granted to the journal.

This is an open-access article distributed under the terms and conditions of the Creative Commons Attribution license (http://creativecommons.org/licenses/by/3.0/). 